\title{
PERSEPSI GURU. KEPALA SEKOLAH, DAN WALI MURID TENTANG FENOMENA KEKERASAN DI DUNIA MAYA TERHADAP ANAK
}

\author{
Hanifah Titi Ananingsih, Muhammad Ragil Kurniawan \\ Universitas Ahmad Dahlan \\ E-mail: hanifahtitiananingsih@gmail.com
}

\begin{abstract}
In the current technological era many children are using social media. Children are more vulnerable to experiencing violence in cyberspace. The role of teachers, principals and guardians of students is needed to prevent the occurrence of violence in cyberspace. This study aims to determine the perceptions of teachers, principals, and guardians of students about the phenomenon of cyber violence against children. The subjects of this study were 4 teachers, 2 school principals, and 4 student guardians. Selection of subjects using purposive sampling technique. The object in this study is the perception of teachers, principals, and guardians of students about child violence in cyberspace. This research is a qualitative research with data collection techniques in the form of observation, interviews, and documentation. The validity of the data uses triangulation techniques with data analysis using an interactive model consisting of data collection, data reduction, display data, and conclusion drawing. The results of the study show that from (1) the cognitive aspects of teachers, principals and guardians of students who know about child violence in cyberspace prevent children from violence in cyberspace. (2) Affective aspects, feelings of teachers, principals and guardians of students are good, if children experience violence in cyberspace feel sad and sad. However, in the context of finding children who experience violence in cyberspace is still classified as passive. Teachers, principals and guardians of students will take action if there is a complaint from the child. (3) Conative aspects, when in school teachers and principals tend to act to prevent violence by advising children, prohibiting the use of mobile phones in schools and not providing internet support facilities for children. At home, guardians provide supervision and advice if children access the internet.
\end{abstract}

Keyword: perceptions, teachers, principals, guardians of students, violence in the Maya world.

\begin{abstract}
ABSTRAK
Di era teknologi sekarang ini anak sudah banyak yang menggunakan media sosial. Anak lebih rentan mengalami kekerasan di dunia maya. Dibutuhkan peran dari guru, kepala sekolah dan wali murid untuk mencegah terjadinya kekerasan di dunia maya. Penelitian ini bertujuan untuk mengetahui persepsi guru, kepala sekolah, dan wali murid tentang fenomena kekerasan di dunia maya terhadap anak. Subjek penelitian ini adalah 4 guru, 2 kepala sekolah, dan 4 wali murid. Pemilihan subjek menggunakan teknik purposive sampling. Objek dalam penelitian ini adalah persepsi guru, kepala sekolah, dan wali murid tentang kekerasan anak di dunia maya. Penelitian ini merupakan penelitian kualitatif dengan teknik pengumpulan data berupa observasi, wawancara, dan
\end{abstract}


dokumentasi. Keabsahan data menggunakan teknik trianggulasi dengan analisis data menggunakan model interaktif yang terdiri dari pengumpulan data, reduksi data, display data, dan penarikan kesimpulan. Hasil penelitian menunjukkan bahwa dilihat dari (1) Aspek kognitif guru, kepala sekolah dan wali murid yang mengetahui tentang kekerasan anak di dunia maya mencegah anak dari kekerasan di dunia maya. (2) Aspek afektif, perasaan guru, kepala sekolah dan wali murid sudah bagus, jika anak mengalami kekerasan di dunia maya merasa sedih dan miris. Namun, dalam konteks menemukan anak yang mengalami kekerasan di dunia maya masih tergolong pasif. Guru, kepala sekolah dan wali murid akan melakukan tindakan apabila ada aduan dari anak. (3) Aspek konatif, saat di sekolah guru dan kepala sekolah cenderung bertindak mencegah terjadinya kekerasan dengan cara menasehati anak, melarang penggunaan HP di sekolah dan tidak menyediakan fasilitas penunjang internet untuk anak. Ketika di rumah, wali murid memberikan pengawasan dan nasehat jika anak mengakses internet.

Keyword: persepsi, guru, kepala sekolah, wali murid, kekerasan di dunia Maya,

\section{PENDAHULUAN}

Di era globalisasi teknologi berkembang dengan sangat pesat. Adanya smartphone dan koneksi internet memudahkan masyarakat untuk mencari informasi secara cepat. Smartphone dan internet dapat menjauhkan sesuatu yang dekat atau sebaliknya mendekatkan sesuatu yang jauh. Kemudahan akses internet membuat masyarakat leluasa menggunakannya. Menurut Ahmadi \& Hermawan (2013:68), Internet adalah komunikasi jaringan komunikasi global yang menghubungkan seluruh komputer di dunia meskipun berbeda sistem operasi dan mesin. Internet identik dengan cyberspace atau dunia maya. Menurut Jati (2016: 25), kemunculan cyberspace melalui sosial media menarik untuk dicermati karena mampu mentransformasi ruang publik dalam bentuk digital. Hal ini berarti bahwa tidak ada yang tahu pasti seberapa luas internet secara fisik. Internet mempunyai peran yang sangat mirip dengan dunia nyata dimana setiap orang bisa berinteraksi dengan orang lain lewat internet.

Masyarakat sekarang ini cenderung melakukan pergeseran aktivitas dari dunia nyata ke dunia maya. Kegiatan beralih ke online, seperti adanya ojek online, belanja online, toko online, dan transaksi online. Hal ini dikarenakan lebih mudah dan praktis, karena cukup bermodalkan smartphone, uang dan koneksi internet kebutuhan masyarakat dapat terpenuhi. Menurut laporan Tetra Pak Index 2017 mencatat ada 132 juta pengguna internet di Indonesia. Sementara hampir setengah dari pengguna internet adalah penggila media sosial yaitu berkisar di angka 40\% (inet.detik.com, 2017).

Adanya media sosial dengan konten yang menarik dan mudah digunakan, membuat pengguna internet semakin bertambah. Pengguna media sosial sendiri adalah orang yang menggunakan media sosial sebagai sarana untuk berkomunikasi dengan masyarakat umum secara online. Pengguna internet di Indonesia didominasi oleh generasi millenial dan generasi Z. Generasi Z, lahir 1995-2010, disebut juga iGeneration, Generasi Net, atau Generasi Internet (Mukhlis, 2015:4). Generasi Z adalah anak yang melek teknologi atau net generation. Mereka lebih menyukai berinteraksi dengan komputer dan berkomunikasi dengan sistem online. (Saragih,2012: 13). Berdasarkan teori tersebut, maka dapat dipastikan bahwa anak sekolah dasar yang tengah duduk dibangku kelas 5 SD pada tahun ini termasuk dalam generasi Z. Dimana dalam teori tersebut dinyatakan bahwa anak senang menelusuri dunia maya. 
Pengguna aktif internet terdiri dari berbagai golongan masyarakat, termasuk di dalamnya adalah anak-anak. Banyaknya pengguna anak-anak didorong oleh semakin mudahnya akses internet. Anak dapat mengakses internet di beragam tempat seperti di rumah, sekolah, warung internet, dan ruang publik. Data BPS mencatat, minat pelajar Provinsi Daerah Istimewa Yogyakarta (DIY) untuk mengakses internet tercatat paling tinggi di banding pelajar dari daerah lain di Indonesia. Persentase siswa DIY yang mengakses internet dalam tiga bulan terakhir menempati posisi tertinggi dengan angka 57,74 persen (antaranews.com, 2016). Namun, bisa jadi anak mengakses internet tidak terkait dengan materi pelajaran di sekolah. Perlu adanya pengawasan dari orang dewasa, seperti guru dan wali murid.

Internet dan media sosial memang membuat anak memperluas jaringan pertemanan dan memudahkan anak untuk mencari informasi. Namun, dampak negatif yang ditimbulkan juga ada. Dampak negatif dari media sosial yang masih sering terjadi akhirakhir ini adalah kasus yang berujung pada kekerasan terhadap anak di dunia maya. Kekerasan anak di dunia maya merupakan bagian dari kekerasan. Kekerasan terhadap anak merupakan perbuatan yang mengkhawatirkan, dimana perbuatan tersebut tidak hanya menyebabkan luka secara fisik tetapi juga psikis. Menurut Soeroso (2010: 80- 82), bentukbentuk kekerasan secara umum dibagi menjadi empat, yaitu 1) kekerasan fisik, 2) kekerasan nonfisik/ psikis/ emosional, 3) kekerasan seksual, 4) kekerasan ekonomi.

Pada masa sekarang, anak-anak Indonesia lebih rentan menjadi korban tindak kekerasan ketimbang zaman dahulu karena terjadi pergeseran nilai (Musbikin, 2009:107). Kemajuan pesat teknologi informasi mempengaruhi kondisi anak zaman sekarang lebih mudah menjadi korban kekerasan. Perilaku anak yang senang mengakses internet membuat anak rentan terhadap bahaya yang ditimbulkan dari dunia maya, seperti pelecehan sosial, bullying, dan pelanggaran privasi. Sehingga sangat penting mengawasi aktivitas anak di dunia maya. Komisi Perlindungan Anak Indonesia (KPAI) mencatat selama 4 tahun terakhir jumlah kekerasan kepada anak terus meningkat. Terakhir di 2014 ada 5.066 kasus. Rata-rata penaikkan kasus dimulai pada tahun 2011 sebanyak 1000 kasus kekerasan. Ada 10 kategori kekerasan pada anak, di antaranya kekerasan dalam keluarga, lembaga pendidikan serta pornografi dan cyber crime. Khusus kekerasan pada anak yang dipicu dari sosial media dan internet sebanyak 322 kasus di tahun 2014. Jumlah terus naik dari tahun 2011 sekitar100 kasus. Kejahatan seksual lewat internet menjadi kategori kasus yang tinggi.Misalnya jumlah korban kejahatan seksual terus naik. Sampai tahun 2014 ada 53 anak yang menjadi korban. Sementara anak pelaku kejahatan online ada 42 anak, anak korban pornografi dari media sosial ada 163 anak. Terakhir anak pelaku kepemilikan media pornografi di video dan diunggah di media sosial ada 64 anak (suara.com, 2015). Kejadian ini menunjukkan kurangnya perhatian dari guru, kepala sekolah, dan wali murid tentang bahaya kekerasan di dunia maya terhadap anak.

Anak kurang mendapatkan pengawasan dari orang dewasa saat mengakses dunia maya. Hasil survei hanya sekitar 50,9 persen anak dan remaja yang menjadi responden riset ini mengaku mendapat petunjuk atau aturan mengakses internet dari orang tua, sekitar 20,8 persen mengaku mendapat bimbingan langsung saat berselancar di dunia maya, serta hanya 16 dari 17 responden yang mengaku berteman dengan orang tua mereka di media sosial (m.hukumonline.com, 2016). Keamanan anak di dunia maya semakin mengkhawatirkan. Beberapa kejahatan di dunia maya bisa terjadi dari apa yang mereka posting. Tindakan kekerasan di dunia maya terhadap anak memang tidak dapat diketahui secara cepat. Belum banyak penelitian terkait fenomena kekerasan di dunia maya terhadap anak. Berdasarkan hasil observasi peneliti dari beberapa jurnal pendidikan belum banyak penelitian terkait dengan fenomena kekerasan di dunia maya terhadap anak. 
Hasil wawancara di lapangan pada tanggal 28 Maret 2018 dengan salah satu siswa SD kelas V di SD SGN (nama samaran) yang berinisial A mengaku memiliki akun instagram namun tidak berteman dengan guru. Alasannya karena anak sudah mengirim permintaan mengikuti (follow) kepada guru, namun guru tidak mengkonfirmasi kembali (follow back) permintaan tersebut. Kenyataan di lapangan banyak orangtua dan guru yang memiliki akun media sosial kurang peduli dengan anak saat di dunia maya. Bisa saja saat anak mengakses media sosial mengalami kekerasan. Mereka tidak menyadari dan menganggap bahwa ada kekerasan di media sosial. Hubungan kedekatan wali murid dan anak penting di dalam sebuah keluarga. Karena ketika anak lebih terbuka kepada walinya, maka kecil kemungkinan mereka untuk memilih media sosial sebagai tempat untuk mencurahkan isi hatinya.

Kurangnya pengetahuan terkait persepsi guru, kepala sekolah, dan wali murid tentang fenomena kekerasan di dunia maya terhadap anak menyebabkan anak rentan terhadap bahaya kekerasan di dunia maya. Hasil penelitian yang dilakukan oleh Arini Rizky Karimah yang berjudul Fenomena Kekerasan di Dunia Maya Terhadap Siswa SD di Kabupaten Sleman (2018) menunjukkan bahwa: bentuk-bentuk kekerasan di dunia maya yang paling banyak dialami siswa kelas V di Kabupaten Sleman yaitu mendapat pesan yang membuat marah dimedia sosial $(11 \%)$, mendapat pesan yang mengganggu dimedia sosial $(10 \%)$, dan mendapat foto tidak sopan dimedia sosial $(9,8 \%)$. Sedangkan, bentukbentuk kekerasan di dunia maya yang paling banyak dilakukan siswa kelas V di Kabupaten Sleman yaitu mengirim pesan yang membuat orang lain marah dimedia sosial $(11,6 \%)$, mengirim pesan yang mengganggu orang lain dimedia sosial $(11,2 \%)$, dan mengomentari foto atau video orang lain dengan kata yang tidak menyenangkan dimedia sosial $(11,2 \%)$. Faktor-faktor penyebab kekerasan di dunia maya terhadap siswa kelas V di Kabupaten Sleman terbesar adalah karena iseng $(12,1 \%)$, benci atau jengkel $(12,1 \%)$ dan alasan yang lainnya $(11,3 \%)$.

Perlu keterlibatan berbagai pihak dalam upaya mempromosikan anti kekerasan terhadap anak di dunia maya. Agar dapat melaksanakan promosi anti kekerasan dengan efektif di sekolah. Sekolah-sekolah itu sendiri harus mengembangkan cara-cara kerja sama yang fleksibel dengan para profesional dalam bidang pendidikan, kesehatan, dan jasa pelayanan sosial serta para komunitas lainnya, dan juga orang tua dan remaja itu sendiri (Cowie \& Jennifer, 2009: 29). Perlunya penyamaan persepsi antara guru, kepala sekolah, dan wali murid dalam menentukan program sekolah yang berhubungan dengan tindakan kekerasan terhadap anak. Menggelar rapat yang dihadiri oleh guru, kepala sekolah, dan wali murid untuk mendiskusikan masalah yang berkaitan dengan kekerasan terhadap anak di dunia maya. Dari rapat tersebut diharapkan dapat menghasilkan program penting yang berhubungan dengan cara mengatasi kekerasan terhadap anak di dunia maya.

Berdasarkan pemaparan latar belakang masalah di atas, dapat disimpulkan bahwa dalam penggunaan jejaring sosial, anak masih sangat membutuhkan kontrol dari orang terdekat. Karena terdapat dampak berbahaya dari adanya kekerasan di dunia maya terhadap anak. Perlu adanya persamaan pemahaman antara guru, kepala sekolah, dan wali murid tentang bahaya kekerasan anak di dunia maya. Dengan demikian peneliti tertarik untuk meneliti sejauh mana persepsi guru, kepala sekolah, dan wali murid tentang fenomena kekerasan di dunia maya terhadap anak. Tempat penelitian yang digunakan dalam penelitian ini berada di dua SD swasta di kabupaten Sleman yang terindikasi memiliki tingkat kekerasan tertinggi menurut penelitian Arini Rizky Karimah yang berjudul Fenomena Kekerasan di Dunia Maya terhadap Siswa SD di Kabupaten Sleman. 


\section{METODE PENELITIAN}

Penelitian ini merupakan penelitian deskriptif kualitatif. Penelitian kualitatif digunakan dalam penelitian ini adalah analisis deskriptif kualitatif. Analisis data dalam penelitian ini yaitu: Pengumpulan Data, Reduksi Data, Display Data, Penarikan Kesimpulan Semua data yang sudah ada akan memiliki suatu analisa tersendiri yang mendukung data yang sudah melalui tahapan-tahapan dari reduksi data dan penyajian data. Sehingga akhirnya ditemukan hipotesis bahkan teori baru sesuai dengan permasalahan yang diteliti yaitu tentang persepsi guru, kepala sekolah, dan wali murid tentang fenomena kekerasan di dunia maya terhadap anak.

\section{HASIL DAN PEMBAHASAN}

Dalam pembahasan yang dilakukan oleh peneliti ini dibahas lebih lanjut mengenai persepsi guru, kepala sekolah dan wali murid tentang fenomena kekerasan di dunia maya terhadap anak sesuai dengan indikator penelitian. Menurut Rakhmat (2015: 50), presepsi adalah memberikan makna pada stimulus indrawi tentang suatu objek, peristiwa/kejadian, atau hubungan-hubungan yang didapatkan dengan menyimpulkan informasi dan menerjemahkan pesan. Dengan mengetahui tentang persepsi guru, kepala sekolah dan wali murid maka akan diketahui pendapat dan pemahaman guru, kepala sekolah dan wali murid tentang fenomena kekerasan di dunia maya terhadap anak. Walgito dalam Sunarru (2011: 36) menyatakan bahwa tiga komponen atau aspek yang membentuk struktur persepsi, yaitu: komponen kognitif (komponen perseptual), komponen afektif (komponen emosional) dan komponen konatif (komponen perilaku).

1. Persepsi Guru, Kepala Sekolah dan Wali Murid tentang Fenomena Kekerasan di Dunia Maya terhadap Anak.

a. Komponen Kognitif

Pengetahuan guru, kepala sekolah dan wali murid tentang fenomena kekerasan di dunia maya terhadap anak. Guru merupakan orang yang mendidik anak secara langsung saat berada di sekolah. Kepala Sekolah merupakan penentu kebijakan di sekolah. Sedangkan, wali murid adalah orang yang bertanggung jawab pada anak saat di rumah. Pemahaman guru, kepala sekolah dan wali murid tentang fenomena kekerasan di dunia maya itu penting. Apabila guru, kepala sekolah dan wali murid sudah memahami tentang fenomena kekerasan di dunia maya terhadap anak maka akan terbentuk pemahaman sehingga menjadi dasar pengetahuan bagi guru, kepala sekolah dan wali murid yang timbul dalam menghadapi fenomena kekerasan di dunia maya terhadap anak, sehingga dapat mencegah terjadinya kekerasan di dunia maya terhadap anak. Persepsi dapat memberikan makna pada stimulasi inderawi, atau menafsirkan informasi yang tertangkap oleh indera. Setiap orang mempunyai persepsi dan pandangan berbeda-beda tentang fenomena kekerasan di dunia maya terhadap anak.

Berdasarkan hasil wawancara dengan guru di 2 SD swasta di Sleman diketahui bahwa guru DP, AG, EN, dan BG mempunyai persepsi negatif terhadap fenomena kekerasan di dunia maya terhadap anak. Pengetahuan guru tentang fenomena kekerasan di dunia maya terhadap anak penting untuk diketahui. Guru dapat menyebutkan tentang apa itu kekerasan terhadap anak dan penyebabnya. Berdasarkan hasil wawancara dengan guru dapat diketahui bahwa: a) Kekerasan di dunia maya terhadap anak adalah kekerasan yang ditemukan di internet. b) Kekerasan terhadap anak di dunia maya itu berbahaya, sama berbahayanya dengan kekerasan di dunia nyata dan dapat merugikan orang lain. c) Kekerasan di dunia maya dapat berupa penyebaran berita bohong di media sosial yang dapat merugikan orang lain. d) Salah satu penyebab kekerasan di dunia maya terhadap anak adalah anak dapat mengakses internet secara bebas di luar lingkungan sekolah dan 
juga terpengaruh oleh teman yang sering menggunakan HP untuk mengakses internet.

Pengetahuan kepala sekolah tentang fenomena kekerasan di dunia maya. Berdasarkan hasil wawancara dan dokumentasi yang telah dilakukan peneliti dapat diketahui bahwa komponen kognitif yang ada pada kepala sekolah adalah a) Kekerasan di dunia maya terhadap anak berbahaya. b) Kepala sekolah meyakini anak tidak mengalami kekerasan di dunia maya saat di sekolah, karena belum pernah ada aduan dari guru terkait kasus kekerasan di dunia maya terhadap anak. Saat di sekolah anak dilarang menggunakan HP. c) Bentuk dari kekerasan di dunia maya berupa menjelekkan orang lain dan pencemaran nama baik di sosial media.Hal ini sejalan dengan Willard dalam Rifauddin (2016: 38) yang menyatakan bahwa bentuk- bentuk cyberbullyng adalah mengiringkan teks berisi kata penuh amarah dan frontal, pesan gangguan, Cyberstalking, Denigration (pencemaran nama baik), Impersonation (peniruan), Outing \& Trickery dan Exclusion (pengeluaran).

Sedangkan pengetahuan wali murid terhadap fenomena kekerasan di dunia maya terhadap anak di dunia maya adalah a) Kekerasan di dunia maya terhadap anak di dunia maya itu berbahaya. b) Bentuk-bentuk kekerasan di dunia maya berupa pornografi, pencemaran nama baik di media sosial, dan menghina orang lain di media sosial. Pengetahuan yang dimiliki guru, kepala sekolah dan wali murid tentang fenomena kekerasan di dunia maya penting untuk diketahui. Sehingga guru, kepala sekolah dan wali murid dapat mencegah terjadinya fenomena tersebut. Hal ini sesuai dengan pendapat Notoatmojo dalam Utomo (2010:22) pengetahuan atau kognitif merupakan domain yang sangat penting dalam membentuk tindakan seseorang (over behavior).

b. Komponen Afektif

Komponen afektif berhubungan dengan kehidupan emosional seseorang menyangkut perasaan individu terhadap objek sikap dan menyangkut masalah emosi. Rasa senang merupakan hal yang positif, sedangkan rasa tidak senang merupakan hal yang negatif. Pada penelitian ini sikap afektif dikhususkan pada perasaan yang dialami guru, kepala sekolah dan wali murid terhadap fenomena kekerasan di dunia maya terhadap anak.

Berdasarkan hasil wawancara dengan subjek guru berinisial DP, AG, EN dan BG terkait fenomena kekerasan di dunia maya terhadap anak. Secara afeksi sudah bagus, guru merasakan sedih dan miris jika anak mengalami kekerasan di dunia maya. Namun, dalam konteks menemukan guru masih dalam konteks pasif, guru menunggu adanya aduan anak dan tidak melakukan tindakan apapun untuk mengetahui kondisi sebenarnya anak. Sampai saat ini DP, AG, EN dan BG tidak merasa apapun, karena belum pernah ada anak yang mengadu mengalami kekerasan di dunia maya.

Perasaan kepala sekolah mengenai fenomena kekerasan di dunia maya terhadap anak adalah kepala Sekolah merasa yakin dan tidak merasa khawatir bahwa anak mengalami kekerasan di dunia maya. Anak-anak masih dapat dikontrol dan dihandel. Selanjutnya hasil wawancara di atas dapat diketahui bahwa komponen afektif yang terjadi pada wali murid HT, ZA, PJ, dan SL terhadap fenomena kekerasan di dunia maya terhadap anak. Terdapat dua hasil yang berbeda. Wali murid HT dan SL merasa sedih dan miris jika ada anak yang mengalami kekerasan di dunia maya. Akan tetapi, mereka saat ini merasa biasa saja karena merasa anak tidak mengalami itu. Wali murid HT dan SL merasa yakin anak tidak mengalami itu, karena anak tidak pernah mengadu. Secara afeksi sudah bagus, wali murid HT dan SL merasa sedih dan miris jika anak mengalami kekerasan di dunia maya. Namun,dalam konteks menemukan wali murid HT dan SL masih tergolong pasif, karena menunggu aduan dari anak.

Selanjurtnya, Wali murid ZA dan PJ merasa khawatir ketika anak mengakses internet sendirian. Merasa was-was jika anak membuka situs aneh-aneh di internet. Tetapi, 
ketika wali murid ZA dan PJ mendampingi anak ketika mengakses internet dan mengecek isi HP-nya tidak menemukan indikasi bahwa anak mengalami kekerasan di dunia maya. Jadi wali murid merasa yakin anak tidak mengalami kekerasan di dunia maya. Perasaan dan emosi pada umumnya disifatkan sebagai keadaan yang ada pada individu atau organisme pada sesuatu waktu.(Mardeli, 2016: 16).

\section{c. Komponen Konatif}

Komponen konatif merupakan kecenderungan bertingkah laku. Cara guru, kepala sekolah dan wali murid dalam menjaga anak supaya anak dapat terhindar dari kekerasan di dunia maya. Berdasarkan hasil wawancara, observasi dan dokumentasi dapat disimpulkan bahwa komponen konatif yang terjadi pada guru yaitu mengawasi saat disekolah dan memberikan nasihat kepada anak untuk mengakses hal yang baik saat membuka internet. Hal ini sesuai dengan pendapat Hinkel dalam Johari (2016: 73) memberi nasihat merupakan satu tindakan linguistik yang kompleks dalam komunikasi dan perlu dilaksanakan mengikut norma-norma kesantunan budaya tertentu. Saat di sekolah, guru mengawasi anak. Anak dilarang membawa HP, jika ketahuan disita. Anak tidak mungkin mengakses internet saat di sekolah, karena di sekolah tidak menyediakan akses internet untuk anak. Namun berbeda saat di dunia maya, sebagian besar guru hanya memiliki WA. Guru tidak berteman dengan anak saat di media sosial. Cara kepala sekolah dalam mencegah kekerasan di dunia maya terhadap anak adalah melarang anak menggunakan HP saat di sekolah. Peraturan tersebut berasal dari dinas. Kepala sekolah sendiri tidak membuat kebijakan khusus terkait penggunaan internet dan kekerasan di dunia maya.

Cara wali murid dalam mencegah fenomena kekerasan di dunia maya terhadap anak adalah mendampingi anak ketika bermain HP, menasehati anak untuk memposting hal baik di internet dan mengecek history pencarian di HP-nya untuk melihat apa saja yang sudah dibuka anak menelusuri internet.

\section{SIMPULAN}

Berdasarkan hasil penelitian yang telah dilakukan dapat diketahui bahwa terdapat persepsi guru, kepala sekolah dan wali murid tentang fenomena kekerasan di dunia maya terhadap anak. Hal ini dapat dilihat dari tiga aspek diantaranya aspek kognitif, aspek afektif dan aspek konatif. (1) Aspek kognitif guru, kepala sekolah dan wali murid yang mengetahui tentang kekerasan anak di dunia maya mencegah anak dari kekerasan di dunia maya. Tetapi guru, kepala sekolah dan wali murid yang tidak mengetahui cenderung diam saja terhadap apa yang dialami anak. (2) Aspek afektif, perasaan guru, kepala sekolah dan wali murid sudah bagus, jika anak mengalami kekerasan di dunia maya merasa sedih dan miris. Namun, dalam konteks menemukan anak yang mengalami kekerasan di dunia maya masih tergolong pasif. Guru, kepala sekolah dan wali murid akan melakukan tindakan apabila ada aduan dari anak. Sampai saat ini belum ada anak yang mengadu mengalami kekerasan di dunia maya. Jadi, guru, kepala sekolah dan wali murid merasa yakin anak tidak mengalaminya. (3) Aspek konatif, saat di sekolah guru dan kepala sekolah cenderung bertindak mencegah terjadinya kekerasan dengan cara membekali anak dengan pengetahuan agama dan pengetahuan umum, menasehati anak, melakukan pengawasan dan kontrol pada anak, melarang penggunaan HP saat di sekolah dan tidak menyediakan fasilitas penunjang internet untuk anak. Ketika di rumah, wali murid menyatakan memberikan pengawasan dan nasehat jika anak mengakses internet.

\section{DAFTAR PUSTAKA}

Ahmadi, Candra \& Dadang, Hermawan. (2013). E-Business \& E-Commerse. Yogyakarta: ANDI. 
Ariefana, Pebriansyah. 2015. Kekerasan pada Anak Dimulai dari Internet. Suara.com. http://suara.com (Online). (Di akses pada tanggal 26 November 2017).

Cowie, H. \& Jennifer, D. 2009. Penanganan kekerasan di sekolah pendekatan lingkup sekolah. Jakarta: Indeks.

Jati, Wasisto Raharjo. (2016). Cyberspace, internet, dan Ruang Publik Baru: Aktivisme Online Politk Kelas Menengah Indonesia. Jurnal Pemikiran Sosiologi, Vol.3 No.1 Januari 2016.

Johari, Arina dan Indirawati Zahid. (2016). Manivestasi Kesantunan Melayu dalam Ujaran Memberi dan Meminta Maaf. GEMA Online ${ }^{\circledR}$ Journal of Language Studies, Volume 16(2).

Karimah, Arini Rizky. (2018). Fenomena Kekerasan di Dunia Maya Terhadap Siswa di Kabupaten Sleman. Skripsi. Yogyakarta: Universitas Ahmad Dahlan.

Mardali. (2010). Teori Kompensasi Emosi. SEMNAS Matematika dan Pend. Matematika 2006. Jurnal Tadrib. Vol. 2 No. 1 Edisi Juni 2016.

Musbikin, Imam. 2009. Mengapa ya anakku kok suka berbohong..?. Yogyakarta:DIVA Press(Anggota IKAPI).

M-25. 2016. Kemenkominfo KomitmenPromosikan Whitelist Situs Bagi Anak. m.hukumonline.com. (Online). (Di akses pada tanggal 21 November 2017).

Napitupulu, RH. 2016. Potensi Besar Bisnis Online. ANTARA News. http://jogja.antaranews.com (Online). (Di akses pada tanggal 21 November 2017).

NN. 2017. Kekerasan Terhadap Anak, Perlu Perpres Pendidikan Ramah Anak.Kompas, 12 November 2017.

Rifauddin, M. 2016. Fenomena Cyberbullying pada Remaja. Jurnal Ilmu Perpustakaan, Informasi, dan Kearsipan Khizanah Al- Hikmah, 4(1), 35-44.

Saragih, John Fredy Bobby. (2012). Fenomena Bermain Generasi Z dan Hubungannya dengan Eksistensi Ruang Bermain Terbuka di Lingkungan Perumahan Sederhana.. Jurnal Comtech. Vol. 3 No. 1 Juni 2012: 8-14.

Soeroso, Hadiati Moerti. 2010. Kekerasan Dalam Rumah Tangga. Jakarta: Sinar Grafika.

Sugiyono. 2015. Metode Penelitian Pendidikan (Pendekatan Kuantitatif, Kualitatif dan $R \& D)$. Bandung: Alfabeta.

Sunarru, Samsi Hariyadi. 2011. Dinamika Kelompok. Yogyakarta: UGM.

Utomo, Hardi. (2010). Hubungan Tingkat Pengetahuan dengan Kemampuan Teknis Masyarakat Kota Salatiga dalam Penggunaan Kompor Gas 3 Kg. Jurnal Among Makarti, Vol.3 No.6, Desember 2010.

Yudhianto. 2017. 132 Juta Pengguna Internet Indonesia, 40\% Penggila Medsos. inet.detik.com. (Online). (Di akses pada tanggal 20 November 2017). 